\title{
Meta-Analysis and Systematic Review in Environmental Tobacco Smoke Risk of Female Lung Cancer by Research Type
}

\author{
Xue Ni, Ning Xu and Qiang Wang * \\ National Institute of Environmental Health, Chinese Center for Disease Control and Prevention, No. 29 Nanwei \\ Road, Beijing 100050, China; nxup2016@163.com (X.N.); xn@nieh.chinacdc.cn (N.X.) \\ * Correspondence: wangqiang@nieh.chinacdc.cn; Tel.: +86-10-5093-0246
}

Received: 6 June 2018; Accepted: 25 June 2018; Published: 27 June 2018

\begin{abstract}
More than 50\% of women worldwide are exposed to Environmental Tobacco Smoke (ETS). The impact of ETS on lung cancer remains unclear. Cohort studies since the late 1990s have provided new evidence of female lung cancer risk due to ETS. The objective of this meta-analysis and systematic review was to analyze the association of ETS with female lung cancer risk from 1997 to 2017, organised based on research design. According to our applied inclusion and exclusion criteria, 41 published studies were included. The relative risk (RR) from the cohort studies or odds ratio (OR) from case-control studies were extracted to calculate the pooled risks based on the type of study. The summary risks of ETS were further explored with the modulators of ETS exposure sources and doses. The pooled risks of lung cancer in non-smoking women exposed to ETS were 1.35 (95\% CI: 1.17-1.56), 1.17 (95\% CI: 0.94-1.44), and 1.33 (95\% CI: 1.17-1.51) for case-control studies, cohort studies, and both types of studies, respectively. The summary RR estimate of the cohort studies was not statistically significant, but the RR increased with increasing doses of ETS exposure ( $p$ trend $<0.05$ ). Based on the results of this study, ETS might be an important risk factor of female lung cancer in non-smokers.
\end{abstract}

Keywords: Environmental Tobacco Smoke; risk; female lung cancer; meta-analysis; study type

\section{Introduction}

Tobacco smoke has been proved to be the main factor influencing the risk of lung cancer. Except for carcinogens in the main stream of tobacco smoke, carcinogens such as benzo[a]pyrene, $N^{\prime}$-nitrosonornicotine (NNN), and (methylnitrosamino)-1-(3-pyridyl)-1-butanone (NNK) are rich in sidestream smoke, also called second-hand smoke [1]. In addition, the pollutants in residual tobacco smoke absorbed by clothing, hair, furnishings, and dust are labelled as third-hand smoke that contribute as a secondary source of indoor Environmental Tobacco Smoke (ETS) [2,3]. Statistics about the global burden of disease related to ETS released by the World Health Organization (WHO) in 2011 showed that the global average proportion of children with at least one smoking parent, according to the definition from Global Youth Tobacco Survey, was estimated to be $41 \%$, and the female adult ETS proportion was about $63 \%$ [4]. Such high prevalence of ETS is causing public health concerns. However, the association of ETS with the risk of lung cancer remains unclear.

Because interviews are convenient, most studies that focused on the relationship between ETS and lung cancer in non-smokers were case-control studies. Most of the case-control studies suggested that ETS might significantly increase lung cancer risk. However, limited to recall bias and relatively small sample size, the evidence provided in these case-control studies was relatively weak. The International Lung Cancer Consortium (ILCCO) pooled 18 case-control studies with pooling data in their databank 
in 2014 [5] and screened a total of 2504 non-smoking lung cancer patients. Their analysis showed a distinct association between ETS and lung cancer risk. After controlling for age, sex, race and ethnicity, and study, the adjusted odds ratio (OR) was 1.31 (95\% confidence interval (CI): 1.17-1.47).

Due to the time, cost, and follow-up issues, the number of cohort studies specific to the association of female lung cancer risk in non-smokers with ETS exposure is quite small. Most of the cohort studies found no significant lung cancer risks [6-12]. In addition, several cohort studies, such as The Women's Health Initiative Observational Study (WHI-OS) [13] and Shanghai Women's Health Study [14], found that the ETS relative risk (RR) of non-smoking female lung cancer was less than 1.0 and the RR was not statistically significant.

Although many meta-analyses have been completed on the association of ETS with lung cancer, the meta-analyses were mostly conducted prior to 2010. Most previous meta-analyses were mixed analyses of female and male lung cancer risk [15-19] or analyzed single exposure sources [20-22]. In addition, many meta-analyses did not distinguish between the risk of lung cancer occurrence and the risk of death [15,22-25]. Although the differences in the types of studies were considered in two of the previous meta-analyses, possibly due to the fewer number of cohort studies, the findings from the two different types of studies were summarized together in a group [15,24]. To the best of our knowledge, cohort studies may have stronger evidence weights than case-control studies, so separately estimating the pooled risks of cohort studies from case-control studies may provide stronger results.

Considerable new evidence about the ETS risks of female lung cancer in non-smokers has emerged since the late 1990s. In particular, some cohort studies provided evidence of the risk of ETS and lung cancer. In order to further clarify the association of ETS with non-smoking female lung cancer risk, the goal of this meta-analysis was to estimate the summarized risk with studies published since 1997 based on the modulator of research type (cohort studies or case-control studies) and by the dose of ETS exposure.

\section{Materials and Methods}

\subsection{Data Collection}

We strictly followed the Preferred Reporting Items for Systematic Reviews and Meta-Analyses (PRISMA) requirements for literature retrieval and writing. The search terms (("lung neoplasms" [MeSH Terms]) OR "lung cancer" [All Fields]) AND (("tobacco smoke pollution" [MeSH Terms]) OR "passive smoking" [All Fields] OR "environmental tobacco smoke" [All Fields] OR "secondhand smoke" [All Fields]) AND (“1997/01/01" [PDAT]: "2017/12/31" [PDAT]) were used to search PubMed and ('lung cancer': ti,ab,kw OR 'lung carcinoma': ti,ab,kw) AND ('environmental tobacco smoke': ti,ab,kw OR 'passive smoking': ti,ab,kw) AND [1997-2017]/py were used as the search string for Embase. We collected the literature on female lung cancer and ETS published from 1997 to 2017. In addition, the references used in each study, the previous meta-analyses about the association of female lung cancer with ETS published publicly, and the reports about female lung cancer projects conducted in various countries were reviewed to select qualified literature.

\subsection{Inclusion and Exclusion Criteria}

We selected studies for the meta-analysis using the following inclusion criteria: (1) a cohort study or a case-control study about ETS and female lung cancer risk published between 1997 and 2017; (2) the number of participants was clearly described; (3) lung cancer cases diagnosed by physicians;

(4) ETS clearly defined; and (5) OR, RR, or detailed data were provided.

We excluded studies using the following rules: (1) the ETS of female participants could not be distinguished distinctly, (2) the rules for participant enrollment were not clearly stated, (3) the study was only about genetic susceptibility of lung cancer, (4) the type of study was neither a cohort study nor a case-control study, (5) the same study was found repeatedly in other journals, (6) a subset of the same study was published elsewhere, (7) the score of quality assessment was relatively lower or the 
quality control of the study was not fully illustrated, and (8) the outcome of the study was death due to lung cancer.

\subsection{Study Selection}

A total of 1494 published studies from 82 different sources were collected. After excluding duplicated records $(n=328)$, we screened studies by title and abstract and 117 studies remained according to our inclusion and exclusion criteria. We then read the full text of the remaining 117 studies. Studies that were impossible to distinguish female ETS exposure [26-36], studies without risk of ETS [37-62], studies that were published more than once, studies with a subset of cases [63-80], studies with lower quality scores (less than five points), and studies about the interaction between gene polymorphism and ETS [81-92] were excluded. In addition, the studies of Seow et al. [93], Edwards [94], and Chen et al. [95], due to the different definitions of ETS, were also excluded. The risk of ETS in studies completed by Schwartz et al. [96] and Ferreccio et al. [97] were reported only as an interactive item, so these two studies were also excluded. The screening process is shown in Figure 1.

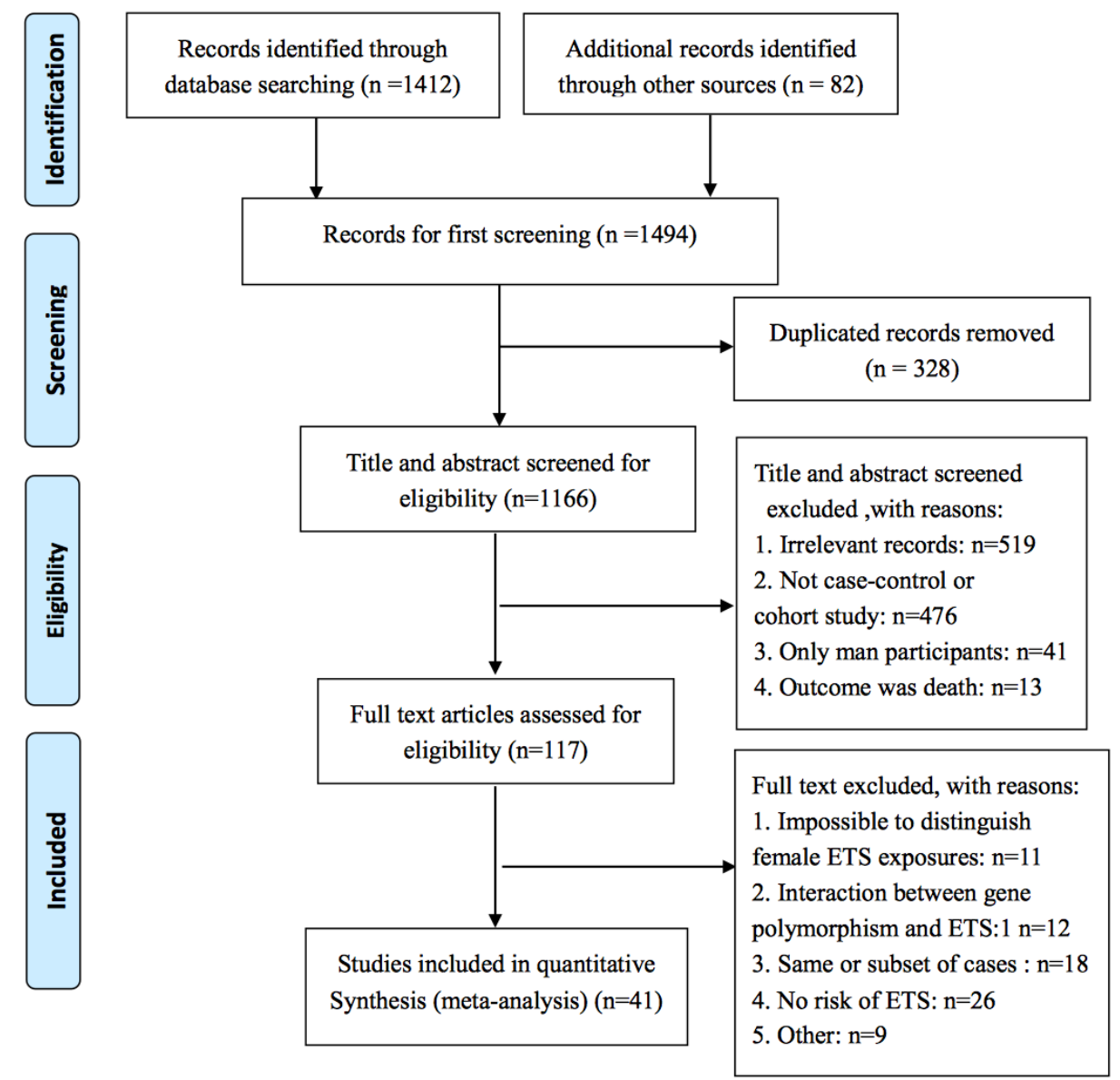

Figure 1. Preferred Reporting Items for Systematic Reviews and Meta-Analyses (PRISMA) literature screening flow diagram.

\subsection{Definition of ETS and Never Smoker}

In this study, ETS was defined as self-reported exposures of never smokers who have been exposed to ETS at family or at workplace at any point in time. We further classified ETS into four categories based on exposure source. The categories of ETS exposures are listed in Table 1.

As for never smokers in this study, never smokers were defined as participants who never smoked or who had smoked less than 100 cigarettes in their lifetime. 
Table 1. Categories of Environmental Tobacco Smoke (ETS) exposures.

\begin{tabular}{|c|c|c|}
\hline ETS Category & Definition & References \\
\hline Workplace ETS & $\begin{array}{l}\text { ETS from smoking colleagues who worked } \\
\text { in the same office or workplace }\end{array}$ & {$[13,98-111]$} \\
\hline Family ETS & $\begin{array}{l}\text { ETS from parents in childhood, husbands of } \\
\text { current smokers or ever smokers, or other } \\
\text { family smokers }\end{array}$ & {$[11,13,98-123]$} \\
\hline Family and Workplace ETS & ETS both from family and workplace & {$[13,98,102,103,109,114,117,121,124]$} \\
\hline Unknown ETS & ETS source was not specified & $\begin{array}{c}{[13,14,99,101-103,105,107-109,113-115,} \\
117,121,124-135]\end{array}$ \\
\hline
\end{tabular}

\subsection{Definition of ETS Exposure Dose}

We classified the ETS dose into the following groups by pack-years, years of exposure, and cigarettes per day:

(1) If the ETS exposure was less than 20 pack-years, then the ETS exposure was defined as low pack-year, and if the ETS exposure was 20 or more pack-years then the ETS exposure was defined as high pack-year.

(2) If the ETS exposure was less than 20 years, then the ETS was defined as short-term ETS, and if the exposure was 20 or more years, then it was defined as long-term ETS.

(3) If the ETS exposure was less than 10 cigarettes per day, then the ETS was defined as light ETS, and if the ETS was 10 cigarettes or more, then it was defined as heavy ETS.

\subsection{Quality Control}

All studies were searched and screened by two authors with the same keywords and rules of literature selection. The literature qualities of case-control or cohort studies were evaluated according to The Newcastle-Ottawa Scale (NOS) [136]. Only studies with five or more points qualified for the meta-analysis. All results of OR, RR, and exposed/unexposed counts of ETS were double entered. In addition, we further proofread the data to ensure accuracy. All studies selected included the ETS risks of female lung cancer.

\subsection{Statistical Analysis}

The $\mathrm{R}$ version 3.4.2 metafor package was used for meta-analysis. OR, RR, or the detailed exposed and unexposed counts were selected as the indicators to estimate the pooled risks and to produce the forest plot. The $\mathrm{Q}$ statistic and the $\mathrm{I}^{2}$ index were used to determine the heterogeneity of the studies [137]. Publication bias was tested by funnel plot and Egger's linear regression method [138]. In addition, sensitivity analysis and publication bias were checked using "trim and fill" non-parametric trimming methods.

\section{Results}

\subsection{Characteristics of Included Studies}

A total of 41 studies were included based on the inclusion and exclusion criteria, including seven cohort studies and 34 case-control studies. Among them, 26 were conducted in Asia, 8 in Europe, and 7 in North America. Meta-analysis showed some heterogeneity in all included studies $\left(\mathrm{I}^{2}=67 \%\right.$, 95\% UI: 55-76\%). The random effect model was used to analyze the pooled effect and the pooled RR was 1.33 (95\% CI: 1.17-1.51). In 8 of the 41 studies, the lung cancer risk of ETS exposure was less than 1.0 and only the OR of one study (Neuberger [120]) found a negative correlation that was statistically significant. The other studies showed the risk increased $(\mathrm{OR} / \mathrm{RR}>1.0)$. 


\subsection{Association of ETS with Female Lung Cancer by Different Study Type}

We found that the heterogeneity of all studies was relatively large, so we stratified all studies according to the type of study. As a result, the pooled RR of seven cohort studies was 1.17 (95\% CI: 0.94-1.44). The RRs in five of the seven studies were larger than $1.0(R R=1.2-1.9)$, and the $R R$ of only one study was statistically significant. The RR in two studies showed that ETS and female lung cancer was negatively associated $(\mathrm{RR}<1.0)$. As to the 34 case-control studies, the pooled OR was 1.35 (95\% CI: 1.17-1.56). Of the 34 studies, 29 were positively related to lung cancer ( $R R>1.0)$ and 10 were statistically significant $(p<0.05)$. Tables 2 and 3 list the summary risks of all studies based on the type of study. As for the confounding effects, meta-regression results showed that there was no statistically significant difference between the adjusted and unadjusted risks $(p=0.59)$.

Table 2. Meta-analysis of the association of female lung cancer with ETS in cohort studies.

\begin{tabular}{cccccc}
\hline Author & Year & Country & RR & 95\% CI & Adjustment \\
\hline Jee et al. [112] & 1999 & Korea & 1.90 & $1.00-3.50$ & $\begin{array}{c}\text { Yes: age, socioeconomic status, residency, } \\
\text { vegetable consumption, occupation }\end{array}$ \\
\hline Speize et al. [125] & 1999 & U.S. & 1.50 & $0.30-6.30$ & Yes: age \\
\hline Nishino et al. [11] & 2001 & Japan & 1.80 & $0.67-4.60$ & $\begin{array}{c}\text { Yes: age, study area, alcohol, diet, history of } \\
\text { lung diseases }\end{array}$ \\
\hline Vineis et al. [126] & 2005 & Europe & 1.20 & $0.71-2.02$ & Yes: age, sex, smoking, country, school years \\
\hline Weiss et al. [14] & 2008 & China & 0.94 & $0.65-1.35$ & No \\
\hline Kurahashi et al. [98] & 2008 & Japan & 1.45 & $0.86-2.44$ & No \\
\hline Wang et al. [13] & 2015 & U.S. & 0.88 & $0.52-1.49$ & $\begin{array}{c}\text { Yes: age, body mass index (BMI), ethnicity, } \\
\text { history of lung cancer, family history of cancer, } \\
\text { education, occupation, hormone therapy use, } \\
\text { oral contraceptive use, fruit servings per day, } \\
\text { vegetable servings per day, red meat serving per } \\
\text { day, alcohol, physical activity }\end{array}$ \\
\hline
\end{tabular}

Table 3. Meta-analysis of the association of female lung cancer with ETS in case-control studies.

\begin{tabular}{|c|c|c|c|c|c|}
\hline Author & Year & Country & OR & $95 \%$ CI & Adjustment \\
\hline Zheng et al. [129] & 1997 & China & 1.04 & $0.59-1.85$ & No \\
\hline Ko ${ }^{1}$ et al. [104] & 1997 & Taiwan & 0.80 & $0.40-1.60$ & $\begin{array}{l}\text { Yes: socioeconomic status, residential } \\
\text { area, education }\end{array}$ \\
\hline Dai et al. [123] & 1997 & China & 3.14 & $1.97-5.01$ & No \\
\hline Boffetta et al. [108] & 1998 & Europe & 1.15 & $0.86-1.55$ & Yes: age, sex \\
\hline Nyberg ${ }^{1}$ et al. [111] & 1998 & Sweden & 0.76 & $0.42-1.37$ & $\begin{array}{l}\text { Yes: age, gender, catchment area, occasional } \\
\text { smoking, vegetable consumption, degree of urban } \\
\text { residence, years of exposure to risk occupation }\end{array}$ \\
\hline Song et al. [127] & 1999 & China & 2.31 & $1.36-3.90$ & No \\
\hline Zhong et al. [103] & 1999 & China & 1.20 & $0.80-1.80$ & $\begin{array}{l}\text { Yes: age, income, intake of vitamin } \mathrm{C} \text {, respondent } \\
\text { status, smokiness of cooking, family history of lung } \\
\text { cancer, occupation }\end{array}$ \\
\hline Zaridze $^{1}$ et al. [106] & 1999 & Russia & 0.88 & $0.55-1.41$ & Yes: age, education \\
\hline Rapiti $^{1}$ et al. [116] & 1999 & India & 1.20 & $0.50-2.90$ & Yes: age, residence, religion \\
\hline Zhou $^{1}$ et al. [100] & 2000 & China & 0.89 & $0.25-3.16$ & No \\
\hline Wang et al. [115] & 2000 & China & 1.15 & $0.60-2.10$ & No \\
\hline Lee et al. [105] & 2000 & Taiwan & 1.88 & $1.36-2.60$ & No \\
\hline Kreuzer et al. [107] & 2000 & Germany & 1.09 & $0.79-1.50$ & No \\
\hline Johnson et al. [117] & 2001 & Canada & 1.32 & $0.66-2.63$ & No \\
\hline Fang et al. [99] & 2002 & China & 2.95 & $1.60-5.47$ & No \\
\hline
\end{tabular}


Table 3. Cont.

\begin{tabular}{|c|c|c|c|c|c|}
\hline Author & Year & Country & OR & $95 \% \mathrm{CI}$ & Adjustment \\
\hline Rachtan [118] & 2002 & Poland & 2.49 & $1.36-4.54$ & $\begin{array}{l}\text { Yes: age, diet, siblings with cancer, tuberculosis, } \\
\text { place of residence, occupational exposure, } \\
\text { pack-years smoking }\end{array}$ \\
\hline Kubík et al. [121] & 2002 & Czech & 1.05 & $0.59-1.86$ & No \\
\hline Chan-Yeung et al. [114] & 2003 & $\begin{array}{l}\text { Hong } \\
\text { Kong }\end{array}$ & 1.57 & $0.92-2.68$ & No \\
\hline Phukan et al. [135] & 2005 & India & 1.56 & $1.02-2.39$ & Yes: age, education, occupational status \\
\hline Yu et al. [124] & 2006 & $\begin{array}{l}\text { Hong } \\
\text { Kong }\end{array}$ & 1.39 & $0.80-2.41$ & No \\
\hline Francomarina et al. [119] & 2006 & Mexico & 1.70 & $1.10-2.80$ & Yes: age, educational level, access to social security \\
\hline Neuberger ${ }^{1}$ et al. [120] & 2006 & U.S. & 0.37 & $0.26-0.54$ & No \\
\hline Gorlova et al. [109] & 2006 & U.S. & 1.27 & $0.82-1.97$ & No \\
\hline Rylander ${ }^{1}$ et al. [110] & 2006 & Sweden & 1.37 & $0.72-2.61$ & No \\
\hline Liang et al. [113] & 2009 & China & 1.43 & $1.00-2.07$ & $\begin{array}{l}\text { Yes: age, marital status, years of schooling, ethnicity, } \\
\text { BMI, } 5 \text { years ago }\end{array}$ \\
\hline Hosseini et al. [132] & 2009 & Iran & 1.50 & $0.80-3.00$ & No \\
\hline Mu et al. [101] & 2013 & China & 1.48 & $0.93-2.35$ & No \\
\hline Lo et al. [102] & 2013 & Taiwan & 1.39 & $1.17-1.67$ & Yes: age, years of education \\
\hline Seki et al. [122] & 2013 & Japan & 1.31 & $0.99-1.72$ & $\begin{array}{l}\text { Yes: age, year of recruitment, area of residence, } \\
\text { referral status, occupation, alcohol drinking, family } \\
\text { history of lung cancer }\end{array}$ \\
\hline Yin et al. [130] & 2014 & China & 1.28 & $0.92-1.79$ & Yes: age \\
\hline Behera et al. [134] & 2014 & India & 2.01 & $0.83-4.92$ & $\begin{array}{l}\text { Yes: smoking, cooking fuel, residence, } \\
\text { occupational history }\end{array}$ \\
\hline Kim et al. [131] & 2015 & U.S. & 1.37 & $0.89-2.10$ & Yes: age, sex, race/ethnicity \\
\hline Ren et al. [133] & 2015 & China & 1.10 & $0.79-1.53$ & No \\
\hline He et al. [128] & 2017 & China & 2.16 & $1.67-2.80$ & No \\
\hline \multicolumn{6}{|c|}{ Pooled OR (Random effect) OR: 1.35, 95\% CI: 1.17-1.56 } \\
\hline
\end{tabular}

${ }^{1}$ Study contained a variety of ETS exposure sources. The risks of all ETS sources could not be pooled with the data reported in the study, so the smallest OR of various ETS risks in the study was used in the meta-analysis.

\subsection{Association of Female Lung Cancer with ETS Based on Exposure Source}

Due to the different ETS risks in two types of studies, we estimated the pooled risks of exposure source based on the strata of the type of study. Table 4 shows that the pooled risk for ETS from the workplace was higher than that from family in both cohort and case-control studies. In addition, we found the pooled OR for ETS from both family and workplace was significantly higher than from any single ETS source in the case-control studies $(p<0.05)$. However, this association was not found in cohort studies.

Table 4. Meta-analysis of ETS exposure source and female lung cancer.

\begin{tabular}{cccccc}
\hline Exposure Source & Number & RR (95\% CI) & $\mathbf{I}^{\mathbf{2}} \mathbf{( 9 5 \%}$ UI) & $p$ Value & Model \\
\hline \multicolumn{7}{c}{ Cohort Studies } \\
\hline Family & 4 & $1.40(1.08-1.82)$ & $0(0-85)$ & 0.61 & Fixed \\
Workplace & 2 & $1.54(0.61-3.91)$ & $74(0-94)$ & 0.05 & Random \\
Family and Workplace & 2 & $1.10(0.71-1.69)$ & $55(0-89)$ & 0.14 & Fixed \\
Unknown & 4 & $0.99(0.77-1.29)$ & $0(0-79)$ & 0.79 & Fixed \\
\hline \multicolumn{7}{c}{ Case-Control Studies } \\
\hline Family & 24 & $1.27(1.05-1.53)$ & $75(64-83)$ & $<0.01$ & Random \\
Workplace & 13 & $1.36(1.21-1.53)$ & $37(0-67)$ & 0.09 & Fixed \\
Family and Workplace & 7 & $1.75(1.43-2.14)$ & $0(0-61)$ & 0.05 & Random \\
Unknown & 23 & $1.43(1.32-1.55)$ & $38(0-71)$ & 0.86 & Fixed \\
\hline
\end{tabular}




\subsection{Association of Female Lung Cancer with ETS Based on Different Exposure Dose}

\subsubsection{Association of Female Lung Cancer with ETS Exposure Dose in Cohort Studies}

According to the exposure doses described in studies, the ETS dose was recorded using one of three methods: pack-year, duration (exposure year), and cigarettes per day. Due to the different definitions of ETS dose in the qualified cohort studies, there were no more than three studies for each category. So this part was not fit for meta-analysis to summarize the RR by ETS dose. Thus, we estimated the dose-response trend and found that the RR significantly increased with increasing dose in four of five studies (Table 5).

Table 5. Overview of the association of ETS dose with female lung cancer in cohort studies.

\begin{tabular}{|c|c|c|c|c|}
\hline Exposure & Study & Exposure Categories & RR (95\% CI) & $p$ Trend \\
\hline Pack-year ${ }^{1}$ & Kurahashi & $\begin{array}{l}<30 \\
\geq 30\end{array}$ & $\begin{array}{l}1.05(0.55-2.02) \\
1.46(0.85-2.50)\end{array}$ & 0.03 \\
\hline \multirow[t]{2}{*}{ Duration(year) } & Wang & $\begin{array}{c}<20 \\
20-30 \\
\geq 30\end{array}$ & $\begin{array}{l}1.11(0.74-1.65) \\
1.11(0.63-1.96) \\
1.61(1.00-2.58)\end{array}$ & 0.24 \\
\hline & Jee & $\begin{array}{l}1-29 \\
\geq 30 \\
\end{array}$ & $\begin{array}{l}1.60(0.80-3.00) \\
3.10(1.40-6.60) \\
\end{array}$ & $<0.01$ \\
\hline \multirow{2}{*}{ Cigarettes/day } & Kurahashi & $\begin{array}{l}<20 \\
\geq 20\end{array}$ & $\begin{array}{l}1.02(0.51-2.04) \\
1.47(0.87-2.49)\end{array}$ & 0.02 \\
\hline & Jee & $\begin{array}{l}1-19 \\
\geq 20\end{array}$ & $\begin{array}{l}2.00(1.10-3.90) \\
1.50(0.70-3.30)\end{array}$ & $<0.10$ \\
\hline
\end{tabular}

Pack-year ${ }^{1}=$ cigarettes smoked every day $/ 20 \times$ smoking year.

\subsubsection{Association of Female Lung Cancer with ETS Exposure Dose in Case-Control Studies}

The pooled risk of ETS dose by pack-years, years of exposure, and cigarettes per day was summarized. Table 6 shows the stratified meta-analysis results of ETS by dose. Stratified by the pack-year of ETS exposure, the meta-analysis showed that the risk of high pack-year was significantly higher than that of low pack-year $(p<0.05)$. As for studies with ETS exposure dose described by exposure years, risk of long-term ETS ( $\geq 20$ years) was not found to be higher than that with short-term, ETS ( $<20$ years) by stratified meta-analysis. As for the studies with ETS exposure dose described by cigarettes per day, stratified meta-analysis showed that neither light ETS ( $<10$ cigarettes per day) nor heavy ETS ( $\geq 10$ cigarettes per day) was significantly associated with increased risk of lung cancer $(p>0.05)$.

Table 6. Stratified meta-analysis of dose association of Environmental Tobacco Smoke (ETS) with female lung cancer in case-control studies.

\begin{tabular}{cccccc}
\hline Exposures & Number & OR (95\% CI) & $\mathbf{I}^{\mathbf{2}} \mathbf{( 9 5 \%}$ UI) & $p$ Value & Model \\
\hline \multicolumn{7}{c}{ Pack-Year } \\
\hline$<20$ & 4 & $0.93(0.77-1.13)$ & $25(0-71)$ & 0.26 & Fixed \\
$\geq 20$ & 3 & $1.74(1.04-2.90)$ & $74(11-92)$ & 0.02 & Random \\
\hline \multicolumn{7}{c}{ Years of Exposure } \\
\hline 20 & 7 & $1.71(1.01-2.90)$ & $79(58-90)$ & $<0.01$ & Random \\
\hline 20 & 6 & $1.57(1.05-2.35)$ & $70(31-87)$ & $<0.01$ & Random \\
\hline \multicolumn{7}{c}{ Cigarettes/Day } \\
\hline 10 & 4 & $1.23(0.90-1.69)$ & $61(0-87)$ & 0.05 & Random \\
\hline & 4 & $1.53(0.69-3.40)$ & $88(72-95)$ & $<0.01$ & Random \\
\hline
\end{tabular}




\subsection{Bias of Publications}

Publication bias was examined by funnel plot and Egger's test. The publication bias was relatively small. The funnel plot was symmetrical (Figure 2), and the Egger's test was not significant $(z=0.42$, $p=0.67)$. When the trim and fill algorithm was used to calibrate the result, the estimated number of missing studies on the right side was zero.

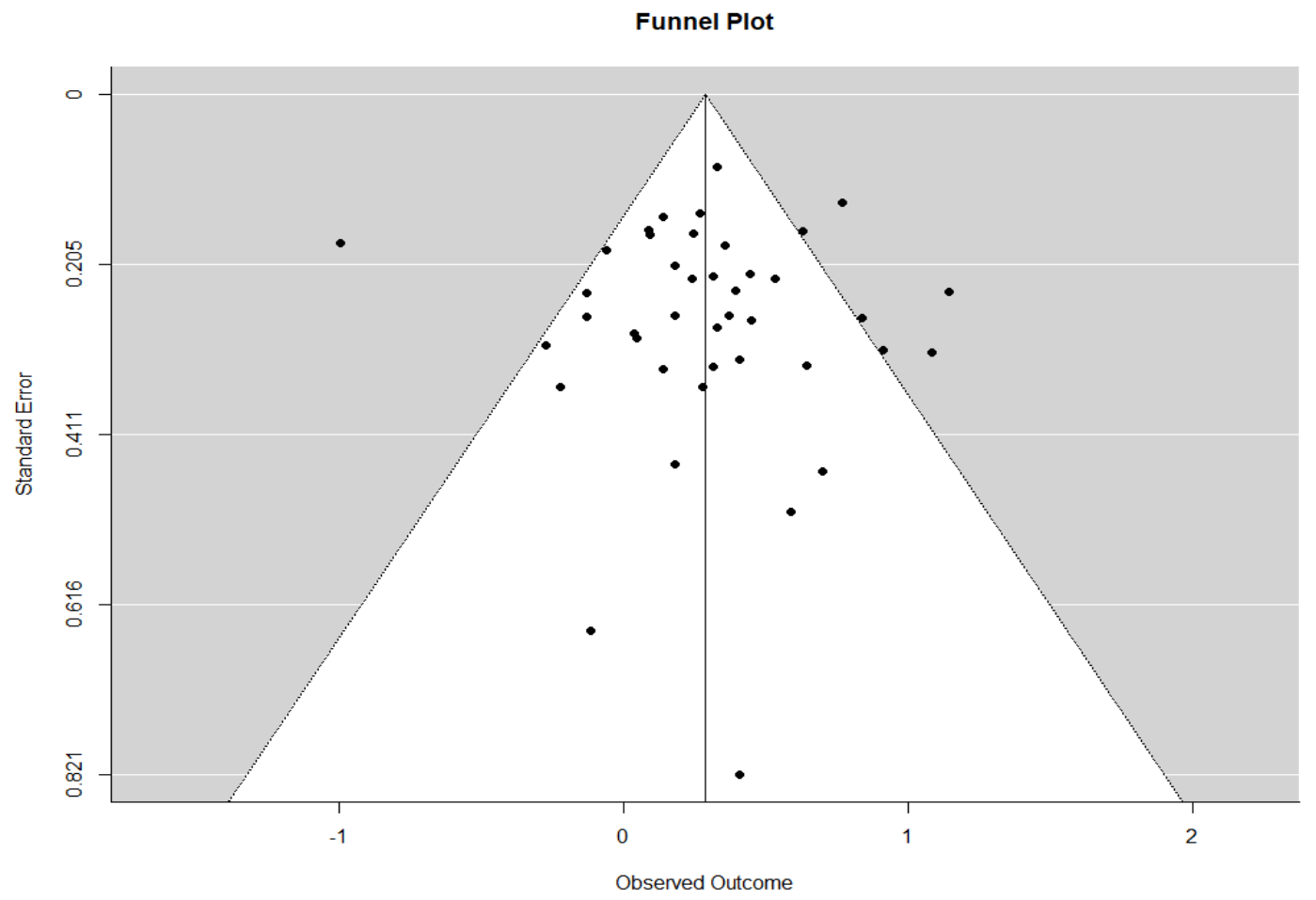

Figure 2. Funnel plot of the association of ETS with female lung cancer.

\subsection{Heterogeneity}

The heterogeneity of the seven included cohort studies was small $\left(\mathrm{I}^{2}=2 \%, 95 \%\right.$ UI: $\left.0-24 \%\right)$; however, the heterogeneity of the case-control studies in our meta-analysis was relatively large $\left(\mathrm{I}^{2}=71 \%, 95 \%\right.$ UI: 59-80\%). The study of Neuberger [120] considerably contributed to the heterogeneity. After removing the study of Neuberger [120], further sensitivity analysis found that $\mathrm{I}^{2}$ dropped to $49 \%$. Table 4 lists the heterogeneity by type of studies and sources of ETS in detail.

\subsection{Previous Meta-Analyses}

A total of 31 meta-analyses were published about the lung cancer risk of ETS: 24 meta-analyses were about the ETS risks from spouses, 11 were about the ETS risks from the workplace, and 7 were about the ETS risks of childhood exposure. As to ETS exposures from spouses, 22 of 24 studies suggested significantly increased risks of ETS. As for workplace ETS exposures, 9 of 11 studies suggested significantly increased risks of ETS. As to childhood ETS exposure, only two studies suggested significantly increased risks. The number of ETS studies included in the previous meta-analyses were different. The summarized risks of ETS varied by meta-analysis; however, the pooled risks in 21 of 31 meta-analyses were in the range of 1.2 to 1.4. Table 7 lists the 31 previous meta-analyses in detail. 
Table 7. Published meta-analyses of ETS and lung cancer.

\begin{tabular}{|c|c|c|c|c|c|}
\hline ID & Author & Number of Studies & Sex & $\begin{array}{l}\text { Pooled OR or RR } \\
(95 \% \mathrm{CI})\end{array}$ & $\begin{array}{l}\text { Exposure } \\
\text { Source }\end{array}$ \\
\hline \multirow{2}{*}{1} & \multirow{2}{*}{ Boffetta et al. [139] } & 45 & $\mathrm{~F}$ & $1.25(1.14-1.38)$ & Spouse \\
\hline & & 15 & $\mathrm{~F}$ & 1.17 (1.02-1.33) & Work \\
\hline 2 & Taylor et al. [22] & 43 & $\mathrm{~F}$ & $1.29(1.17-1.43)$ & Spouse \\
\hline \multirow{3}{*}{3} & \multirow{3}{*}{ Lee et al. [15] } & 93 & $\mathrm{~F}$ & $1.22(1.14-1.31)$ & Spouse \\
\hline & & 47 & $\mathrm{~F}$ and $\mathrm{M}$ & $1.22(1.15-1.30)$ & Work \\
\hline & & 41 & $\mathrm{~F}$ and $\mathrm{M}$ & $1.15(1.02-1.29)$ & Childhood \\
\hline \multirow{3}{*}{4} & \multirow{3}{*}{ Zhong et al. [23] } & 40 & $\mathrm{~F}$ & $1.20(1.12-1.29)$ & Spouse \\
\hline & & 14 & $\mathrm{~F}$ & $1.15(1.04-1.28)$ & Work \\
\hline & & 18 & $\mathrm{~F}$ & $0.89(0.81-0.98)$ & Childhood \\
\hline 5 & Hackshaw et al. [140] & 37 & $\mathrm{~F}$ & $1.24(1.13-1.36)$ & Spouse \\
\hline 6 & Taylor et al. [25] & 55 & $\mathrm{~F}$ & 1.27 (1.17-1.37) & Spouse \\
\hline 7 & Gross [141] & 31 & $\mathrm{~F}$ & $1.18(1.06-1.28)$ & Spouse \\
\hline 8 & Wang [21] & 6 & $\mathrm{~F}$ & $0.91(0.75-1.10)$ & Spouse \\
\hline \multirow{2}{*}{9} & \multirow{2}{*}{ Tweedie et al. [142] } & 36 & F & $1.22(1.08-1.37)$ & Spouse \\
\hline & & 9 & $\mathrm{~F}$ & $1.10(0.90-1.32)$ & Work \\
\hline 10 & $\begin{array}{l}\text { U.S. National Research } \\
\text { Council [143] }\end{array}$ & 13 & $\mathrm{~F}$ & $1.32(1.16-1.52)$ & Spouse \\
\hline 11 & Blot et al. [144] & 12 & $\mathrm{~F}$ & $1.30(1.10-1.50)$ & Spouse \\
\hline 12 & Wells [145] & 17 & $\mathrm{~F}$ & $1.44(1.26-1.66)$ & Spouse \\
\hline 13 & Lee [146] & 28 & $\mathrm{~F}$ & 1.18 (1.07-1.30) & Spouse \\
\hline 14 & $\begin{array}{c}\text { U.S. Environmental } \\
\text { Protective Agency [147] }\end{array}$ & 11 & $\mathrm{~F}$ & $1.19(1.01-1.39)$ & Spouse \\
\hline 15 & Pershagen [148] & 25 & $\mathrm{~F}$ & $1.23(1.11-1.36)$ & Spouse \\
\hline 16 & Mengersen et al. [149] & 34 & $\mathrm{~F}$ & $1.23(1.08-1.41)$ & Spouse \\
\hline 17 & Dockery [150] & 33 & $\mathrm{~F}$ & $1.27(1.18-1.38)$ & Spouse \\
\hline \multirow{3}{*}{18} & \multirow{3}{*}{ Zhao et al. [151] } & 4 & $\mathrm{~F}$ and $\mathrm{M}$ & $1.18(0.80-1.74)$ & Spouse \\
\hline & & 5 & $\mathrm{~F}$ and $\mathrm{M}$ & $1.41(1.19-1.66)$ & Work \\
\hline & & 3 & $\mathrm{~F}$ and $\mathrm{M}$ & $1.04(0.86-1.27)$ & Childhood \\
\hline 19 & Wald et al. [152] & 13 & $\mathrm{~F}$ and $\mathrm{M}$ & $1.35(1.20-1.53)$ & Spouse \\
\hline 20 & Saracci et al. [153] & 14 & $\mathrm{~F}$ and $\mathrm{M}$ & $1.35(1.20-1.53)$ & Spouse \\
\hline 21 & Law et al. [154] & 34 & $\mathrm{~F}$ and $\mathrm{M}$ & $1.24(1.11-1.38)$ & Spouse \\
\hline 22 & Merletti et al. [18] & 39 & $\mathrm{~F}$ and $\mathrm{M}$ & $1.24(1.15-1.34)$ & Spouse \\
\hline 23 & Tweedie et al. [155] & 26 & $\mathrm{~F}$ & $1.17(1.06-1.28)$ & Spouse \\
\hline \multirow{2}{*}{24} & \multirow{2}{*}{ Li et al. [156] } & 5 & $\mathrm{~F}$ and $\mathrm{M}$ & $1.15(1.00-1.33)$ & Spouse \\
\hline & & 2 & $\mathrm{~F}$ and $\mathrm{M}$ & $1.21(1.09-1.34)$ & Childhood \\
\hline \multirow{2}{*}{25} & \multirow{2}{*}{ Yu et al. [157] } & 8 & $\mathrm{~F}$ & $1.47(1.28-1.69)$ & Work \\
\hline & & 8 & $\mathrm{~F}$ & $0.99(0.85-1.15)$ & Childhood \\
\hline 26 & Stayner et al. [19] & 22 & $\mathrm{~F}$ and $\mathrm{M}$ & $1.24(1.18-1.29)$ & Work \\
\hline \multirow[b]{2}{*}{27} & \multirow{2}{*}{ Fu et al. [158] } & 12 & $\mathrm{~F}$ and $\mathrm{M}$ & $1.38(1.13-1.69)$ & Work \\
\hline & & 5 & $\mathrm{~F}$ and $\mathrm{M}$ & $1.37(0.98-1.91)$ & Childhood \\
\hline 28 & Wells [16] & 5 & $\mathrm{~F}$ and $\mathrm{M}$ & 1.39 (1.15-1.68) & Work \\
\hline 29 & Brown et al. [20] & 14 & $\mathrm{~F}$ & $1.25(1.08-1.41)$ & Work \\
\hline 30 & Levois et al. [159] & 12 & $\mathrm{~F}$ and $\mathrm{M}$ & $1.01(0.92-1.11)$ & Work \\
\hline 31 & Boffetta et al. [17] & 10 & $\mathrm{~F}$ and $\mathrm{M}$ & $0.91(0.80-1.05)$ & Childhood \\
\hline
\end{tabular}

\section{Discussion}

We retrieved studies on the association of female lung cancer with ETS from 1997 to 2017. We found a weak association of ETS with female lung cancer, with the risk of lung cancer increasing by 
about 33\%. Our result was similar to that of the International Agency for Research on Cancer (IARC) ETS assessment in 2012. However, we found the association was inconsistent between cohort and case-control studies. We tried to compare our results with those of previous published meta-analyses but all 31 meta-analyses did not distinguish the outcome (death or newly developed cases) in their pooled estimates. In only two of the meta-analyses were the pooled risks of ETS summarized by type of study (Taylor [22], Zhong [23]). However, the two meta-analyses did not limit the outcome to death or new case. The pooled risk of ETS in Taylor's meta-analysis [22] for case-control studies was similar with our result, but the pooled risks of the cohort studies of the two meta-analyses were somewhat different from our result. The pooled RRs in their meta-analyses suggested a significantly increased risk of lung cancer for ETS exposure. The pooled RR estimate in our meta-analysis was similar to that of Taylor [22], but the pooled risk was not significant due to the two new cohort studies included.

Based on the difference in pooled risks between cohort and case-control studies, we further analyzed the association between female lung cancer and ETS source or ETS dose based on type of study. First, for risks based on exposure source, we did not find a higher risk of exposure to multiple sources than from a single source of ETS in cohort studies, but we found an association in case-control studies. Due to the availability of uniformed ETS doses, comparing multiple ETS exposure doses to single ETS exposures or to sum ETS doses by different source for different designs of previously published studies was not feasible. Thus, the risk of multiple ETS sources needs to be validated in subsequent large sample studies. This is also one of the uncertainties in our analysis. As to the risk of ETS doses, we found a consistency in dose trend in both cohort and case-control studies. We observed a significant trend in the exposure doses of ETS in five cohort studies. In case-control studies, we found dose trends in pack-year or cigarettes per day; the dose trend of pack-year was statistically significant.

Based on the results of Egger's test and the trim and fill algorithm, the inclusion of the studies was relatively reasonable. The Egger's test was not statistically significant and the pooled risk was not updated after the calibration of the trim and fill algorithm. All the studies included in this meta-analysis were papers in peer reviewed journals and therefore some publication bias may exist. Fortunately, the number of unpublished studies of ETS and lung cancer was quite small [160].

In addition, seven studies in our meta-analysis reported the risks of multiple ETS exposure sources. Pooling the risks of the seven studies was impossible due to lack of counts of exposed and unexposed of single-specified ETS sources. For these seven studies, we chose the smallest OR of all sources as the inputs for our meta-analysis. This may have been one of the sources of heterogeneity. As a result, the pooled risk in our study is relatively conservative.

Although the association of ETS with lung cancer has been studied for a long time, the exposure classification is not uniform in all studies and various designs have been used for ETS exposure assessments. Fewer studies assessed ETS exposure based on exposure biomarkers for internal doses. To the best of our knowledge, previous studies showed that the association of ETS with lung cancer risk was relatively weak and the association might be confounded. Aging is one of the known confounders of lung cancer. So, age was adjusted in most studies for the ETS risk of lung cancer. Our meta-regression results showed that regardless of whether age was adjusted, the summary risks of ETS did not change significantly. We hypothesize that the reason for the minimal difference between crude risks and the adjusted risks is that the confounding effects of age might be relatively weaker. Apart from age, the common confounding factors of the ETS risk of lung cancer include air pollution, low fruit intake, radon exposure, and some occupational carcinogens. However, the limited difference may also be due to the difficulty of obtaining data or the smaller risks of some factors. Few studies have controlled these factors when estimating the adjusted risk of ETS exposure. Whether the ETS risk of lung cancer is significantly confounded by the above-mentioned risks must to be further explored in the future studies.

Furthermore, the proportion of pathological diagnosis for lung cancer cases in these studies was quite low and the misclassification of cases cannot be ignored. All these factors might limit the association of ETS with female lung cancer, which creates uncertainties in this study. 


\section{Conclusions}

In summary, the results of case-control studies and cohort studies were not consistent, but the dose trends in the association of ETS with female lung cancer indicated that heavy exposures of ETS, especially for ETS exposures for more than 20 years, is the dominant determinant of lung cancer risk of ETS, irrespective of type of study. Due to the high proportion of ETS worldwide, the impact of ETS on female lung cancer is an important public health concern.

Author Contributions: Q.W. conceived the paper and screened the literature. X.N. screened the literature, discussed the results, and contributed substantially to the analysis. N.X. screened the literature.

Funding: This research was funded by National Health Commission of the People's Republic of China. 131031108000160005.

Conflicts of Interest: The authors declare no conflict of interest.

\section{References}

1. IARC Working Group on the Evaluation of Carcinogenic Risks to Humans. Tobacco smoke and involuntary smoking. IARC Monogr. Eval. Carcinog. Risks Hum. 2004, 83, 1-1438.

2. Matt, G.E.; Quintana, P.J.; Destaillats, H.; Gundel, L.A.; Sleiman, M.; Singer, B.C.; Jacob, P.; Benowitz, N.; Winickoff, J.P.; Rehan, V.; et al. Thirdhand tobacco smoke: Emerging evidence and arguments for a multidisciplinary research agenda. Environ. Health Perspect. 2011, 119, 1218-1226. [CrossRef] [PubMed]

3. Protano, C.; Vitali, M. The new danger of thirdhand smoke: Why passive smoking does not stop at secondhand smoke. Environ. Health Perspect. 2011, 119, A422. [CrossRef] [PubMed]

4. Öberg, M.; Woodward, A.; Jaakkola, M.S.; Peruga, A.; Prüssüstün, A.; Öberg, M.; Woodward, A.; Jaakkola, M.S.; Peruga, A.; Prüssüstün, A. Global estimate of the burden of disease from second-hand smoke. Available online: http://www.who.int/tobacco/publications/global_estimate_burden_disease_ second_hand_smoke/en/ (accessed on 18 May 2018).

5. Kim, C.H.; Lee, Y.C.; Hung, R.J.; McNallan, S.R.; Cote, M.L.; Lim, W.Y.; Chang, S.C.; Kim, J.H.; Ugolini, D.; Chen, Y.; et al. Exposure to secondhand tobacco smoke and lung cancer by histological type: A pooled analysis of the international lung cancer consortium (ilcco). Int. J. Cancer 2014, 135, 1918-1930. [CrossRef] [PubMed]

6. Butler, T.I. The Relationship on Passive Smoking to Various Health Outcomes among Seventh-Day Adventists in California. Ph.D.Thesis, University of California, Los Angeles, CA, USA, 1988.

7. Cardenas, V.M.; Thun, M.J.; Austin, H.; Lally, C.A.; Clark, W.S.; Greenberg, R.S.; Heath, C.J. Environmental tobacco smoke and lung cancer mortality in the american cancer society's cancer prevention study. II. Cancer Causes Control 1997, 8, 57-64. [CrossRef] [PubMed]

8. Garfinkel, L. Time trends in lung cancer mortality among nonsmokers and a note on passive smoking. J. Natl. Cancer Inst. 1981, 66, 1061-1066. [CrossRef] [PubMed]

9. Enstrom, J.E.; Kabat, G.C. Environmental tobacco smoke and tobacco related mortality in a prospective study of californians, 1960-98. BMJ 2003, 326, 1057. [CrossRef] [PubMed]

10. Hole, D.J.; Gillis, C.R.; Chopra, C.; Hawthorne, V.M. Passive smoking and cardiorespiratory health in a general population in the west of scotland. BMJ 1989, 299, 423-427. [CrossRef] [PubMed]

11. Nishino, Y.; Tsubono, Y.; Tsuji, I.; Komatsu, S.; Kanemura, S.; Nakatsuka, H.; Fukao, A.; Satoh, H.; Hisamichi, S. Passive smoking at home and cancer risk: A population-based prospective study in Japanese nonsmoking women. Cancer Causes Control 2001, 12, 797-802. [CrossRef] [PubMed]

12. Hill, S.E.; Blakely, T.; Kawachi, I.; Woodward, A. Mortality among lifelong nonsmokers exposed to secondhand smoke at home: Cohort data and sensitivity analyses. Am. J. Epidemiol. 2007, 165, 530-540. [CrossRef] [PubMed]

13. Wang, A.; Kubo, J.; Luo, J.; Desai, M.; Hedlin, H.; Henderson, M.; Chlebowski, R.; Tindle, H.; Chen, C.; Gomez, S.; et al. Active and passive smoking in relation to lung cancer incidence in the women's health initiative observational study prospective cohort. Ann. Oncol. 2015, 26, 221-230. [CrossRef] [PubMed]

14. Weiss, J.M.; Lacey, J.J.; Shu, X.O.; Ji, B.T.; Hou, L.; Yang, G.; Li, H.; Rothman, N.; Blair, A.; Gao, Y.T.; et al. Menstrual and reproductive factors in association with lung cancer in female lifetime nonsmokers. Am. J. Epidemiol. 2008, 168, 1319-1325. [CrossRef] [PubMed] 
15. Lee, P.N.; Fry, J.S.; Forey, B.A.; Hamling, J.S. Environmental tobacco smoke exposure and lung cancer: A systematic review. World J. Meta-Anal. 2016, 4, 10-43. [CrossRef]

16. Wells, A.J. Lung cancer from passive smoking at work. Am. J. Public Health 1998, 88, 1025-1029. [CrossRef] [PubMed]

17. Boffetta, P.; Tredaniel, J.; Greco, A. Risk of childhood cancer and adult lung cancer after childhood exposure to passive smoke: A meta-analysis. Environ. Health Perspect. 2000, 108, 73-82. [CrossRef] [PubMed]

18. Merletti, F.; Richiardi, L.; Boffeta, P. Health effects of passive smoking. Med. del Lavoro 1998, 89, 149-163.

19. Stayner, L.; Bena, J.; Sasco, A.J.; Smith, R.; Steenland, K.; Kreuzer, M.; Straif, K. Lung cancer risk and workplace exposure to environmental tobacco smoke. Am. J. Public Health 2007, 97, 545-551. [CrossRef] [PubMed]

20. Brown, K.G. Lung cancer and environmental tobacco smoke: Occupational risk to nonsmokers. Environ. Health Perspect. 1999, 107, 885-890. [CrossRef] [PubMed]

21. Wang, T.J.; Zhou, B.S. Meta-analysis of the potential relationship between exposure to environmental tobacco smoke and lung cancer in nonsmoking chinese women. Lung Cancer 1997, 16, 145-150. [CrossRef]

22. Taylor, R.; Najafi, F.; Dobson, A. Meta-analysis of studies of passive smoking and lung cancer: Effects of study type and continent. Int. J. Epidemiol. 2007, 36, 1048-1059. [CrossRef] [PubMed]

23. Zhong, L.; Goldberg, M.S.; Parent, M.E.; Hanley, J.A. Exposure to environmental tobacco smoke and the risk of lung cancer: A meta-analysis. Lung Cancer 2000, 27, 3-18. [CrossRef]

24. Hori, M.; Tanaka, H.; Wakai, K.; Sasazuki, S.; Katanoda, K. Secondhand smoke exposure and risk of lung cancer in Japan: A systematic review and meta-analysis of epidemiologic studies. Jpn. J. Clin. Oncol. 2016, 46, 942-951. [CrossRef] [PubMed]

25. Taylor, R.; Cumming, R.; Woodward, A.; Black, M. Passive smoking and lung cancer: A cumulative meta-analysis. Aust. N. Z. J. Public Health 2001, 25, 203-211. [CrossRef] [PubMed]

26. Yu, M.; Rao, K.; Chen, Y. A case-control study of the risk factors of lung cancer in Beijing, Tianjin, Shanghai, Chongqing metropolitan areas. Chin. J. Prev. Med. 2000, 34, 227-231.

27. Chen, K.X.; Xu, W.L.; Jia, Z.L.; Yu, M.; Wang, Q.S.; Dong, S.F.; Wang, J.F. Risk factors of lung cancer in Tianjin. Chin. J. Oncol. 2003, 25, 575-580.

28. Villeneuve, P.J.; Jerrett, M.; Brenner, D.; Su, J.; Chen, H.; McLaughlin, J.R. A case-control study of long-term exposure to ambient volatile organic compounds and lung cancer in Toronto, Ontario, Canada. Am. J. Epidemiol. 2014, 179, 443-451. [CrossRef] [PubMed]

29. Olivo-Marston, S.E.; Yang, P.; Mechanic, L.E.; Bowman, E.D.; Pine, S.R.; Loffredo, C.A.; Alberg, A.J.; Caporaso, N.; Shields, P.G.; Chanock, S.; et al. Childhood exposure to secondhand smoke and functional mannose binding lectin polymorphisms are associated with increased lung cancer risk. Cancer Epidemiol. Biomark. Prev. 2009, 18, 3375-3383. [CrossRef] [PubMed]

30. Gorlova, O.Y.; Weng, S.F.; Hernandez, L.; Spitz, M.R.; Forman, M.R. Dietary patterns affect lung cancer risk in never smokers. Nutr. Cancer 2011, 63, 842-849. [CrossRef] [PubMed]

31. Torres-Duran, M.; Ruano-Ravina, A.; Kelsey, K.T.; Parente-Lamelas, I.; Leiro-Fernandez, V.; Abdulkader, I.; Provencio, M.; Abal-Arca, J.; Castro-Anon, O.; Montero-Martinez, C.; et al. Environmental tobacco smoke exposure and egfr and alk alterations in never smokers' lung cancer. Results from the lcrins study. Cancer Lett. 2017, 411, 130-135. [CrossRef] [PubMed]

32. Boffetta, P.; Ahrens, W.; Nyberg, F.; Mukeria, A.; Bruske-Hohlfeld, I.; Fortes, C.; Constantinescu, V.; Simonato, L.; Batura-Gabryel, H.; Lea, S.; et al. Exposure to environmental tobacco smoke and risk of adenocarcinoma of the lung. Int. J. Cancer 1999, 83, 635-639. [CrossRef]

33. Jin, Z.Y.; Wu, M.; Han, R.Q.; Zhang, X.F.; Wang, X.S.; Liu, A.M.; Zhou, J.Y.; Lu, Q.Y.; Kim, C.H.; Mu, L.; et al. Household ventilation may reduce effects of indoor air pollutants for prevention of lung cancer: A case-control study in a Chinese population. PLoS ONE 2014, 9, e102685. [CrossRef] [PubMed]

34. Raaschou-Nielsen, O.; Andersen, Z.J.; Hvidberg, M.; Jensen, S.S.; Ketzel, M.; Sørensen, M.; Loft, S.; Overvad, K.; Tjønneland, A. Lung cancer incidence and long-term exposure to air pollution from traffic. Environ. Health Perspect. 2011, 119, 860-865. [CrossRef] [PubMed]

35. Couraud, S.; Debieuvre, D.; Moreau, L.; Dumont, P.; Margery, J.; Quoix, E.; Duvert, B.; Cellerin, L.; Baize, N.; Taviot, B.; et al. No impact of passive smoke on the somatic profile of lung cancers in never-smokers. Eur. Respir. J. 2015, 45, 1415-1425. [CrossRef] [PubMed] 
36. Eng, L.; Su, J.; Qiu, X.; Palepu, P.R.; Hon, H.; Fadhel, E.; Harland, L.; La Delfa, A.; Habbous, S.; Kashigar, A.; et al. Second-hand smoke as a predictor of smoking cessation among lung cancer survivors. J. Clin. Oncol. 2014, 32, 564-570. [CrossRef] [PubMed]

37. Xiang, Y.; Gao, Y.; Zhong, L.; Jin, F.; Sun, L.; Cheng, J.; Zhai, Y. A case-control study on relationship between body mass index and lung cancer in non-smoking women. Chin. J. Prev. Med. 1999, 33, 9-12.

38. Neuberger, M.; Moshammer, H. Suspended particulates and lung health. Wien. Klin. Wochenschr. Suppl. 2004, 116, 8-12.

39. Bromen, K.; Pohlabeln, H.; Jahn, I.; Ahrens, W.; Jockel, K.H. Aggregation of lung cancer in families: Results from a population-based case-control study in Germany. Am. J. Epidemiol. 2000, 152, 497-505. [CrossRef] [PubMed]

40. Seersholm, N.; Hertz, H.; Olsen, J.H. Cancer in the offspring of parents with lung cancer. Eur. J. Cancer 1997, 33, 2376-2379. [CrossRef]

41. Gunbatar, H.; Sertogullarindan, B.; Ozbay, B.; Avcu, S.; Bulut, G.; Kosem, M. Chronic effects of environmental biomass smoke on lung histopathology in Turkish non-smoking women: A case series. Arh. Hig. Rada Toksikol. 2012, 63, 357-365. [CrossRef] [PubMed]

42. Ozturk, A.; Sarihan, S.; Ercan, I.; Karadag, M. Evaluating quality of life and pulmonary function of long-term survivors of non-small cell lung cancer treated with radical or postoperative radiotherapy. Am. J. Clin. Oncol. 2009, 32, 65-72. [CrossRef] [PubMed]

43. Wünsch-Filho, V.; Boffetta, P.; Colin, D.; Moncau, J.E. Familial cancer aggregation and the risk of lung cancer. Sao Paulo Med. J. 2002, 120, 38-44. [CrossRef] [PubMed]

44. Jonsson, S.; Thorsteinsdottir, U.; Gudbjartsson, D.F.; Jonsson, H.H.; Kristjansson, K.; Arnason, S.; Gudnason, V.; Isaksson, H.J.; Hallgrimsson, J.; Gulcher, J.R.; et al. Familial risk of lung carcinoma in the icelandic population. JAMA 2004, 292, 2977-2983. [CrossRef] [PubMed]

45. Lan, Q.; He, X. Molecular epidemiological studies on the relationship between indoor coal burning and lung cancer in Xuan Wei, China. Toxicology 2004, 198, 301-305. [CrossRef] [PubMed]

46. Fujita, S.; Masago, K.; Takeshita, J.; Togashi, Y.; Hata, A.; Kaji, R.; Kokubo, M.; Katakami, N. Multiple primary malignancies in patients with non-small cell lung cancer. Intern. Med. 2015, 54, 325-331. [CrossRef] [PubMed]

47. Seow, A.; Zhao, B.; Poh, W.T.; Teh, M.; Eng, P.; Wang, Y.T.; Tan, W.C.; Lee, E.J.; Lee, H.P. Nat2 slow acetylator genotype is associated with increased risk of lung cancer among non-smoking chinese women in Singapore. Carcinogenesis 1999, 20, 1877-1881. [CrossRef] [PubMed]

48. Masjedi, M.R.; Naghan, P.A.; Taslimi, S.; Yousefifard, M.; Ebrahimi, S.M.; Khosravi, A.; Karimi, S.; Hosseini, M.; Mortaz, E. Opium could be considered an independent risk factor for lung cancer: A case-control study. Respiration 2013, 85, 112-118. [CrossRef] [PubMed]

49. Vähäkangas, K.H.; Bennett, W.P.; Castrén, K.; Welsh, J.A.; Khan, M.A.; Blömeke, B.; Alavanja, M.C.R.; Harris, C.C. P53 and K-ras mutations in lung cancers from former and never-smoking women. Cancer Res. 2001, 61, 4350-4356. [PubMed]

50. Fang, X.; Yin, Z.; Li, X.; Xia, L.; Zhou, B. Polymorphisms in GEMIN4 and AGO1 genes are associated with the risk of lung cancer: A case-control study in Chinese female non-smokers. Int. J. Environ. Res. Public Health 2016, 13, 939. [CrossRef] [PubMed]

51. Laurila, A.L.; Anttila, T.; Läärä, E.; Bloigu, A.; Virtamo, J.; Albanes, D.; Leinonen, M.; Saikku, P. Serological evidence of an association between chlamydia pneumoniae infection and lung cancer. Int. J. Cancer 1997, 74, 31-34. [CrossRef]

52. Das, A.; Krishnamurthy, A.; Ramshankar, V.; Sagar, T.G.; Swaminathan, R. The increasing challenge of never smokers with adenocarcinoma lung: Need to look beyond tobacco exposure. Indian J. Cancer 2017, 54, 172-177. [CrossRef] [PubMed]

53. Comstock, G.W.; Alberg, A.J.; Huang, H.Y.; Wu, K.; Burke, A.E.; Hoffman, S.C.; Norkus, E.P.; Gross, M.; Cutler, R.G.; Morris, J.S.; et al. The risk of developing lung cancer associated with antioxidants in the blood: Ascorbic acid, carotenoids, alpha-tocopherol, selenium, and total peroxyl radical absorbing capacity. Cancer Epidemiol. Biomark. Prev. 1997, 6, 907-916. [CrossRef] [PubMed] 
54. Ruano-Ravina, A.; Torres-Durán, M.; Barros-Dios, J.; Raíces, M.; Pérez-Ríos, M.; Abal-Arca, J.; Parente, I.; Leiro, V.; Montero-Martínez, C.; Pena, C.; et al. Residential radon and lung cancer in never smokers. Preliminary results of the lung cancer risk factors in never smokers (LCRINS) study. Am. J. Epidemiol. 2013, 177, S126. [CrossRef]

55. García-Sancho, C.F.; Fernández-Plata, R.; de la Garza, M.S.R.; Mora-Pizano, M.A.; Martínez-Briseño, D.; Franco-Marina, F.; Pérez-Padilla, J.R. Wood smoke as a risk factor for lung cancer nonsmoking population hospitalized. Rev. Inst. Nac. Enferm. Respir. 2012, 71, 325-332.

56. Leung, C.C.; Hui, L.; Lam, T.H.; Yew, W.W.; Law, W.S.; Tam, C.M. Tuberculosis increases the risk of lung cancer death in the elderly. Am. J. Respir. Crit. Care Med. 2012, 185, A6781.

57. Mulcahy, M.; Evans, D.S.; Hammond, S.K.; Repace, J.L.; Byrne, M. Secondhand smoke exposure and risk following the irish smoking ban: An assessment of salivary cotinine concentrations in hotel workers and air nicotine levels in bars. Tob. Control 2005, 14, 384-388. [CrossRef] [PubMed]

58. Neuberger, J.S.; Gesell, T.F. Residential radon exposure and lung cancer: Risk in nonsmokers. Health Phys. 2002, 83, 1-18. [CrossRef] [PubMed]

59. Mu, L.; Bonner, M.; Irla, A.; Jin, J.; Olson, J.; Ellison, C.; Zhang, Z.F. Mitochondrial DNA copy number and lung cancer risk among Chinese female non-smoker. Cancer Res. 2012, 72, 5481. [CrossRef]

60. Lagarde, F.; Axelsson, G.; Damber, L.; Mellander, H.; Nyberg, F.; Pershagen, G. Residential radon and lung cancer among never-smokers in Sweden. Epidemiology 2001, 12, 396-404. [CrossRef] [PubMed]

61. Maoa, Y.; Hua, J.; Ugnata, A.M.; Semenciwa, R.; Finchamb, S. Socioeconomic status and lung cancer risk in canada. Int. J. Epidemiol. 2001, 30, 809-817. [CrossRef]

62. Nyberg, F.; Isaksson, I.; Harris, J.R.; Pershagen, G. Misclassification of smoking status and lung cancer risk from environmental tobacco smoke in never-smokers. Epidemiology 1997, 8, 304-309. [CrossRef] [PubMed]

63. Qin, Y.; Zhou, B.; Xu, Z. A case-control study on risk factor of lung cancer in female nonsmokers. Chin. J. Lung Cancer 2002, 5, 98-100.

64. Nyberg, F.; Agudo, A.; Boffetta, P.; Fortes, C.; González, C.A.; Pershagen, G. A european validation study of smoking and environmental tobacco smoke exposure in nonsmoking lung cancer cases and controls. Cancer Causes Control 1998, 9, 173-182. [CrossRef] [PubMed]

65. Lin, Y.; Cai, L. Environmental and dietary factors and lung cancer risk among chinese women: A case-control study in Southeast China. Nutr. Cancer 2012, 64, 508-514. [CrossRef] [PubMed]

66. Papathomas, M.; Molitor, J.; Richardson, S.; Riboli, E.; Vineis, P. Examining the joint effect of multiple risk factors using exposure risk profiles: Lung cancer in nonsmokers. Environ. Health Perspect. 2011, 119, 84-91. [CrossRef] [PubMed]

67. Chen, K.Y.; Hsiao, C.F.; Chang, G.C.; Tsai, Y.H.; Su, W.C.; Perng, R.P.; Huang, M.S.; Hsiung, C.A.; Chen, C.J.; Yang, P.C. Hormone replacement therapy and lung cancer risk in Chinese. Cancer 2007, 110, 1768-1775. [CrossRef] [PubMed]

68. Hu, J.; Mao, Y.; Dryer, D.; White, K.; Paulse, B.; Dewar, R.; Kreiger, N.; Whittaker, H.; Robson, D.; Fincham, S.; et al. Risk factors for lung cancer among canadian women who have never smoked. Cancer Detect. Prev. 2002, 26, 129-138. [CrossRef]

69. Kreuzer, M.; Heinrich, J.; Kreienbrock, L.; Rosario, A.S.; Gerken, M.; Wichmann, H.E. Risk factors for lung cancer among nonsmoking women. Int. J. Cancer 2002, 100, 706-713. [CrossRef] [PubMed]

70. Wu, Q.J.; Xiang, Y.B.; Yang, G.; Li, H.L.; Lan, Q.; Gao, Y.T.; Zheng, W.; Shu, X.O.; Fowke, J.H. Vitamin E intake and the lung cancer risk among female nonsmokers: A report from the shanghai women's health study. Int. J. Cancer 2015, 136, 610-617. [CrossRef] [PubMed]

71. Zatloukal, P.; Kubík, A.; Pauk, N.; Tomášek, L.; Petruzelka, L. Adenocarcinoma of the lung among women: Risk associated with smoking, prior lung disease, diet and menstrual and pregnancy history. Lung Cancer 2003, 41, 283-293. [CrossRef]

72. Wang, X.R.; Chiu, Y.L.; Qiu, H.; Au, J.S.; Yu, I.T. The roles of smoking and cooking emissions in lung cancer risk among chinese women in Hong Kong. Ann. Oncol. 2009, 20, 746-751. [CrossRef] [PubMed]

73. Wang, L.; Li, Y. Lung cancer in the Chinese passive smoking populations. Value Health 2009, 12 , A37. [CrossRef]

74. Yang, S.Y.; Hsiung, C.N.; Li, Y.J.; Chang, G.C.; Tsai, Y.H.; Chen, K.Y.; Huang, M.S.; Su, W.C.; Chen, Y.M.; Hsiung, C.A.; et al. Fanconi anemia genes in lung adenocarcinoma- a pathway-wide study on cancer susceptibility. J. Biomed. Sci. 2016, 23, 23. [CrossRef] [PubMed] 
75. Vineis, P.; Veglia, F.; Garte, S.; Malaveille, C.; Matullo, G.; Dunning, A.; Peluso, M.; Airoldi, L.; Overvad, K.; Raaschou-Nielsen, O.; et al. Genetic susceptibility according to three metabolic pathways in cancers of the lung and bladder and in myeloid leukemias in nonsmokers. Ann. Oncol. 2007, 18, 1230-1242. [CrossRef] [PubMed]

76. Veglia, F.; Vineis, P.; Overvad, K.; Boeing, H.; Bergmann, M.M.; Trichopoulou, A.; Trichopoulos, D.; Palli, D.; Krogh, V.; Tumino, R.; et al. Occupational exposures, environmental tobacco smoke, and lung cancer. Epidemiology 2007, 18, 769-775. [CrossRef] [PubMed]

77. Baltar, V.T.; Xun, W.W.; Chuang, S.C.; Relton, C.; Ueland, P.M.; Vollset, S.E.; Midttun, O.; Johansson, M.; Slimani, N.; Jenab, M.; et al. Smoking, secondhand smoke, and cotinine levels in a subset of EPIC cohort. Cancer Epidemiol. Biomark. Prev. 2011, 20, 869-875. [CrossRef] [PubMed]

78. Takata, Y.; Shu, X.O.; Yang, G.; Li, H.; Dai, Q.; Gao, J.; Cai, Q.; Chow, W.H.; Gao, Y.; Zheng, W. Association between dietary calcium intake and lung cancer risk in female non-smokers: A report from the shanghai women's health study. Cancer Res. 2012, 72. [CrossRef]

79. Cai, Q.; Gao, Y.T.; Wen, W.; Milne, G.L.; Yang, G.; Ji, B.T.; Rothman, N.; Li, H.L.; Shu, X.O.; Chow, W.H.; et al. Prospective study of urinary prostaglandin E2 metabolite and lung cancer risk. Cancer Res. 2010, 70. [CrossRef]

80. Fowke, J.H.; Gao, Y.T.; Chow, W.H.; Cai, Q.; Shu, X.O.; Li, H.L.; Ji, B.T.; Rothman, N.; Yang, G.; Chung, F.L.; et al. Urinary isothiocyanate levels and lung cancer risk among non-smoking women: A prospective investigation. Lung Cancer 2011, 73, 18-24. [CrossRef] [PubMed]

81. Soo, R.A.; Kubo, A.; Ando, M.; Kawaguchi, T.; Ahn, M.J.; Ou, S.H.I. Association between environmental tobacco smoke exposure and the occurrence of egfr mutations and alk rearrangements in never-smokers with non-small-cell lung cancer: Analyses from a prospective multinational ets registry. Clin. Lung Cancer 2017, 18, 535-542. [CrossRef] [PubMed]

82. Bennett, W.P.; Alavanja, M.C.R.; Blomeke, B.; Vähäkangas, K.H.; Castrén, K.; Welsh, J.A.; Bowman, E.D.; Khan, M.A.; Flieder, D.B.; Harris, C.C. Environmental tobacco smoke, genetic susceptibility, and risk of lung cancer in never-smoking women. J. Natl. Cancer Inst. 1999, 91, 2009-2014. [CrossRef] [PubMed]

83. Han, L.; Lee, C.K.; Pang, H.; Chan, H.T.; Lo, I.L.; Lam, S.K.; Cheong, T.H.; Ho, J.C. Genetic predisposition to lung adenocarcinoma among never-smoking chinese with different epidermal growth factor receptor mutation status. Lung Cancer 2017, 114, 79-89. [CrossRef] [PubMed]

84. Bonner, M.R.; Bennett, W.P.; Xiong, W.; Lan, Q.; Brownson, R.C.; Harris, C.C.; Field, R.W.; Lubin, J.H.; Alavanja, M.C. Radon, secondhand smoke, glutathione-s-transferase $\mathrm{m} 1$ and lung cancer among women. Int. J. Cancer 2006, 119, 1462-1467. [CrossRef] [PubMed]

85. Hedley, A.J.; McGhee, S.M.; Repace, J.L.; Wong, L.C.; Yu, M.Y.; Wong, T.W.; Lam, T.H. Risks for heart disease and lung cancer from passive smoking by workers in the catering industry. Toxicol. Sci. 2006, 90, 539-548. [CrossRef] [PubMed]

86. Wilson, S.E.; Talaska, G.; Kahn, R.S.; Schumann, B.; Khoury, J.; Leonard, A.C.; Lanphear, B.P. White blood cell DNA adducts in a cohort of asthmatic children exposed to environmental tobacco smoke. Int. Arch. Occup. Environ. Health 2011, 84, 19-27. [CrossRef] [PubMed]

87. Kubo, A.; Ando, M.; Soo, R.; Kawaguchi, T.; Ou, S.H.I.; Ahn, M.J. Impacts of environmental tobacco smoke on EGFR mutations and ALK rearrangements in never smokers with non-small cell lung cancer: Analyses on a prospective multinational ETS registry. J. Thorac. Oncol. 2013, 8. [CrossRef]

88. Ryan, B.M.; Robles, A.I.; McClary, A.C.; Bowman, E.; Vahakangas, K.; Olivo-Marston, S.; Yang, P.; Jen, J.; Harris, C.C. Interaction between $\mathrm{drd} 1$ and childhood exposure to environmental tobacco smoke modulates lung cancer risk in smokers and never smokers. Cancer Res. 2013, 73. [CrossRef]

89. Yang, L.; Lv, X.X.; Ling, X.X.; Song, J.L.; Ji, W.D.; Bin, X.N.; Lv, J.C. Association between the genetic variant in CHRNA3 promoter and lung cancer risk in passive smoking population. Chin. J. Cancer Prev. Treat. 2010, 17, 972-975, 990.

90. Kiyohara, C.; Wakai, K.; Mikami, H.; Sido, K.; Ando, M.; Ohno, Y. Risk modification by CYP1A1 and GSTM1 polymorphisms in the association of environmental tobacco smoke and lung cancer: A case-control study in Japanese nonsmoking women. Int. J. Cancer 2003, 107, 139-144. [CrossRef] [PubMed]

91. Nyberg, F.; Hou, S.M.; Hemminki, K.; Lambert, B.; Pershagen, G. Glutathione S-transferase $\mu 1$ and $\mathrm{N}$-acetyltransferase 2 genetic polymorphisms and exposure to tobacco smoke in nonsmoking and smoking lung cancer patients and population controls. Cancer Epidemiol. Biomark. Prev. 1998, 7, 875-883. 
92. Miller, D.P.; De Vivo, I.; Neuberg, D.; Wain, J.C.; Lynch, T.J.; Su, L.; Christiani, D.C. Association between self-reported environmental tobacco smoke exposure and lung cancer: Modification by GSTP1 polymorphism. Int. J. Cancer 2003, 104, 758-763. [CrossRef] [PubMed]

93. Seow, A.; Poh, W.T.; Teh, M.; Eng, P.; Wang, Y.T.; Tan, W.C.; Chia, K.S.; Yu, M.C.; Lee, H.P. Diet, reproductive factors and lung cancer risk among Chinese women in Singapore: Evidence for a protective effect of soy in nonsmokers. Int. J. Cancer 2002, 97, 365-371. [CrossRef] [PubMed]

94. Edwards, R. Spousal smoking as an indicator of total secondhand smoke exposure. Nicot. Tob. Res. 2009, 11, 606-613. [CrossRef] [PubMed]

95. Chen, B.; Cao, H.; Wang, D.; Liu, D.; Zeng, J.; Wang, Y.; Zhang, S.; Gao, J.; Yu, J.; Li, W. Design and application of a self-evaluation questionnaire for individuals at a high-risk of lung cancer. Thorac. Cancer 2012, 3, 60-67. [CrossRef] [PubMed]

96. Schwartz, A.G.; Cote, M.L.; Wenzlaff, A.S.; Van Dyke, A.; Chen, W.; Ruckdeschel, J.C.; Gadgeel, S.; Soubani, A.O. Chronic obstructive lung diseases and risk of non-small cell lung cancer in women. J. Thorac. Oncol. 2009, 4, 291-299. [CrossRef] [PubMed]

97. Ferreccio, C.; Yuan, Y.; Calle, J.; Benitez, H.; Parra, R.L.; Acevedo, J.; Smith, A.H.; Liaw, J.; Steinmaus, C. Arsenic, tobacco smoke, and occupation: Associations of multiple agents with lung and bladder cancer. Epidemiology 2013, 24, 898-905. [CrossRef] [PubMed]

98. Kurahashi, N.; Inoue, M.; Liu, Y.; Iwasaki, M.; Sasazuki, S.; Sobue, T.; Tsugane, S. Passive smoking and lung cancer in Japanese non-smoking women: A prospective study. Int. J. Cancer 2008, 122, 653-657. [CrossRef] [PubMed]

99. Fang, J.; Gan, D.K.; Zheng, S.H.; Zhang, H.W. A case-control study of the risk factors for lung cancer among chinese women who have never smoked. J. Hyg. Res. 2006, 35, 464-467.

100. Zhou, B.S.; Wang, T.J.; Guan, P.; Wu, J.M. Indoor air pollution and pulmonary adenocarcinoma among females: A case-control study in Shenyang, China. Oncol. Rep. 2000, 7, 1253-1259. [CrossRef] [PubMed]

101. Mu, L.; Liu, L.; Niu, R.; Zhao, B.; Shi, J.; Li, Y.; Swanson, M.; Scheider, W.; Su, J.; Chang, S.C.; et al. Indoor air pollution and risk of lung cancer among Chinese female non-smokers. Cancer Causes Control 2013, 24, 439-450. [CrossRef] [PubMed]

102. Lo, Y.L.; Hsiao, C.F.; Chang, G.C.; Tsai, Y.H.; Huang, M.S.; Su, W.C.; Chen, Y.M.; Hsin, C.W.; Chang, C.H.; Yang, P.C.; et al. Risk factors for primary lung cancer among never smokers by gender in a matched case-control study. Cancer Causes Control 2013, 24, 567-576. [CrossRef] [PubMed]

103. Zhong, L.; Goldberg, M.S.; Gao, Y.T.; Jin, F. A case-control study of lung cancer and environmental tobacco smoke among nonsmoking women living in Shanghai, China. Cancer Causes Control 1999, 10, 607-616. [CrossRef] [PubMed]

104. Ko, Y.C.; Lee, C.H.; Chen, M.J.; Huang, C.C.; Chang, W.Y.; Lin, H.J.; Wang, H.Z.; Chang, P.Y. Risk factors for primary lung cancer among non-smoking women in Taiwan. Int. J. Epidemiol. 1997, 26, 24-31. [CrossRef] [PubMed]

105. Lee, C.H.; Ko, Y.C.; Goggins, W.; Huang, J.J.; Huang, M.S.; Kao, E.L.; Wang, H.Z. Lifetime environmental exposure to tobacco smoke and primary lung cancer of non-smoking Taiwanese women. Int. J. Epidemiol. 2000, 29, 224-231. [CrossRef] [PubMed]

106. Zaridze, D.; Maximovitch, D.; Zemlyanaya, G.; Aitakov, Z.N.; Boffetta, P. Exposure to environmental tobacco smoke and risk of lung cancer in non- smoking women from Moscow, Russia. Int. J. Cancer 1998, 75, 335-338. [CrossRef]

107. Kreuzer, M.; Gerken, M.; Kreienbrock, L.; Wellmann, J.; Wichmann, H.E. Lung cancer in lifetime nonsmoking men-Results of a case-control study in Germany. Br. J. Cancer 2001, 84, 134-140. [CrossRef] [PubMed]

108. Boffetta, P.; Agudo, A.; Ahrens, W.; Benhamou, E.; Benhamou, S.; Darby, S.C.; Ferro, G.; Fortes, C.; Gonzalez, C.A.; Jöckel, K.H.; et al. Multicenter case-control study of exposure to environmental tobacco smoke and lung cancer in Europe. J. Natl. Cancer Inst. 1998, 90, 1440-1450. [CrossRef] [PubMed]

109. Gorlova, O.Y.; Zhang, Y.; Schabath, M.B.; Lei, L.; Zhang, Q.; Amos, C.I.; Spitz, M.R. Never smokers and lung cancer risk: A case-control study of epidemiological factors. Int. J. Cancer 2006, 118, 1798-1804. [CrossRef] [PubMed]

110. Rylander, R.; Axelsson, G. Lung cancer risks in relation to vegetable and fruit consumption and smoking. Int. J. Cancer 2006, 118, 739-743. [CrossRef] [PubMed] 
111. Nyberg, F.; Agrenius, V.; Svartengren, K.; Svensson, C.; Pershagen, G. Environmental tobacco smoke and lung cancer in nonsmokers: Does time since exposure play a role? Epidemiology 1998, 9, 301-308. [CrossRef] [PubMed]

112. Jee, S.H.; Ohrr, H.; Kim, I.S. Effects of husbands' smoking on the incidence of lung cancer in Korean women. Int. J. Epidemiol. 1999, 28, 824-828. [CrossRef] [PubMed]

113. Liang, H.Y.; Li, X.L.; Yu, X.S.; Guan, P.; Yin, Z.H.; He, Q.C.; Zhou, B.S. Facts and fiction of the relationship between preexisting tuberculosis and lung cancer risk: A systematic review. Int. J. Cancer 2009, 125, 2936-2944. [CrossRef] [PubMed]

114. Chan-Yeung, M.; Koo, L.C.; Ho, J.C.M.; Tsang, K.W.T.; Chau, W.S.; Chiu, S.W.; Ip, M.S.M.; Lam, W.K. Risk factors associated with lung cancer in Hong Kong. Lung Cancer 2003, 40, 131-140. [CrossRef]

115. Wang, L.; Lubin, J.H.; Zhang, S.R.; Metayer, C.; Xia, Y.; Brenner, A.; Shang, B.; Wang, Z.; Kleinerman, R.A. Lung cancer and environmental tobacco smoke in a non-industrial area of China. Int. J. Cancer 2000, 88, 139-145. [CrossRef]

116. Rapiti, E.; Jindal, S.K.; Gupta, D.; Boffetta, P. Passive smoking and lung cancer in Chandigarh, India. Lung Cancer 1999, 23, 183-189. [CrossRef]

117. Johnson, K.C.; Hu, J.; Mao, Y. Lifetime residential and workplace exposure to environmental tobacco smoke and lung cancer in never-smoking women, Canada 1994-97. Int. J. Cancer 2001, 93, 902-906. [CrossRef] [PubMed]

118. Rachtan, J. Smoking, passive smoking and lung cancer cell types among women in Poland. Lung Cancer 2002, 35, 129-136. [CrossRef]

119. Franco-Marina, F.; Villalba Caloca, J.; Corcho-Berdugo, A.; Pérez, C.I.; Morales, F.M.; Sabido, R.C.; Casanova Ma, E.R.; Schnweeiss, L.G.; Acevedo, E.C.; Díaz, E.T.; et al. Role of active and passive smoking on lung cancer etiology in Mexico City. Salud Publica Mex. 2006, 48 (Suppl. 1), S75-S82. [CrossRef] [PubMed]

120. Neuberger, J.S.; Mahnken, J.D.; Mayo, M.S.; Field, R.W. Risk factors for lung cancer in Iowa women: Implications for prevention. Cancer Detect. Prev. 2006, 30, 158-167. [CrossRef] [PubMed]

121. Kubik, A.K.; Zatloukal, P.; Tomasek, L.; Petruzelka, L. Lung cancer risk among Czech women: A case-control study. Prev. Med. 2002, 34, 436-444. [CrossRef] [PubMed]

122. Seki, T.; Nishino, Y.; Tanji, F.; Maemondo, M.; Takahashi, S.; Sato, I.; Kawai, M.; Minami, Y. Cigarette smoking and lung cancer risk according to histologic type in Japanese men and women. Cancer Sci. 2013, 104, 1515-1522. [CrossRef] [PubMed]

123. Dai, W.C.; Wang, S.Y.; Chen, Y. Fraction analysis of the involvement of multiple risk factors in the etiology of lung cancer: Risk factor interactions in a case-control study for lung cancer in females. Zhonghua Liu Xing Bing Xue Za Zhi 1997, 18, 341-344. [PubMed]

124. Yu, I.T.; Chiu, Y.L.; Au, J.S.; Wong, T.W.; Tang, J.L. Dose-response relationship between cooking fumes exposures and lung cancer among Chinese nonsmoking women. Cancer Res. 2006, 66, 4961-4967. [CrossRef] [PubMed]

125. Speizer, F.E.; Colditz, G.A.; Hunter, D.J.; Rosner, B.; Hennekens, C. Prospective study of smoking, antioxidant intake, and lung cancer in middle-aged women (USA). Cancer Causes Control 1999, 10, 475-482. [CrossRef] [PubMed]

126. Vineis, P.; Airoldi, L.; Veglia, F.; Olgiati, L.; Pastorelli, R.; Autrup, H.; Dunning, A.; Garte, S.; Gormally, E.; Hainaut, P.; et al. Environmental tobacco smoke and risk of respiratory cancer and chronic obstructive pulmonary disease in former smokers and never smokers in the epic prospective study. BMJ 2005, 330, 277. [CrossRef] [PubMed]

127. Song, L.; Yan, W.; Dai, X. Indoor air pollution and women lung cancer. J. Environ. Health 1999, 16, $201-202$.

128. He, F.; Xie, J.X.; Liu, C.L.; Xiong, W.M.; Xu, Q.P.; Liu, Z.Q.; Lin, T.; Xiao, R.D.; Li, X.; Cai, L. The relationship of lung cancer with menstrual and reproductive factors may be influenced by passive smoking, cooking oil fumes, and tea intake: A case-control study in Chinese women. Medicine 2017, 96, e8816. [CrossRef] [PubMed]

129. Zheng, S.; Fan, R.; Wu, Z. Studies on relationship between passive smoking and lung cancer in non-smoking women. Chin. J. Prev. Med. 1997, 31, 163-165.

130. Yin, Z.H.; Cui, Z.G.; Ren, Y.W.; Su, M.; Ma, R.; He, Q.C.; Zhou, B.S. Tp63 gene polymorphisms, cooking oil fume exposure and risk of lung adenocarcinoma in Chinese non-smoking females. Asian Pac. J. Cancer Prev. 2014, 14, 6519-6522. [CrossRef] [PubMed] 
131. Kim, C.H.; Lee, Y.C.; Hung, R.J.; Boffetta, P.; Xie, D.; Wampfler, J.A.; Cote, M.L.; Chang, S.C.; Ugolini, D.; Neri, M.; et al. Secondhand tobacco smoke exposure and lung adenocarcinoma in situ/minimally invasive adenocarcinoma (AIS/MIA). Cancer Epidemiol. Biomark. Prev. 2015, 24, 1902-1906. [CrossRef] [PubMed]

132. Hosseini, M.; Naghan, P.A.; Karimi, S.; SeyedAlinaghi, S.; Bahadori, M.; Khodadad, K.; Mohammadi, F.; Kaynama, K.; Masjedi, M.R. Environmental risk factors for lung cancer in Iran: A case-control study. Int. J. Epidemiol. 2009, 38, 989-996. [CrossRef] [PubMed]

133. Ren, Y.; Yin, Z.; Li, K.; Wan, Y.; Li, X.; Wu, W.; Guan, P.; Zhou, B. TGFß-1 and TGFBR2 polymorphisms, cooking oil fume exposure and risk of lung adenocarcinoma in Chinese nonsmoking females: A case control study. BMC Med. Genet. 2015, 16, 22. [CrossRef] [PubMed]

134. Behera, D.; Balamugesh, T. Indoor air pollution as a risk factor for lung cancer in women. J. Assoc. Phys. India 2005, 53, 190-192.

135. Phukan, R.K.; Saikia, B.J.; Borah, P.K.; Zomawia, E.; Sekhon, G.S.; Mahanta, J. Role of household exposure, dietary habits and glutathione S-transferases M1, T1 polymorphisms in susceptibility to lung cancer among women in Mizoram India. Asian Pac. J. Cancer Prev. 2014, 15, 3253-3260. [CrossRef] [PubMed]

136. Stang, A. Critical evaluation of the Newcastle-Ottawa scale for the assessment of the quality of nonrandomized studies in meta-analyses. Eur. J. Epidemiol. 2010, 25, 603-605. [CrossRef] [PubMed]

137. Von Hippel, P.T. The heterogeneity statistic I(2) can be biased in small meta-analyses. BMC Med. Res. Methodol. 2015, 15, 35. [CrossRef] [PubMed]

138. Egger, M.; Davey, S.G.; Schneider, M.; Minder, C. Bias in meta-analysis detected by a simple, graphical test. BMJ 1997, 315, 629-634. [CrossRef] [PubMed]

139. Boffetta, P. Involuntary smoking and lung cancer. Scand. J. Work Environ. Health 2002, 28, 30-40. [PubMed]

140. Hackshaw, A.K.; Law, M.R.; Wald, N.J. The accumulated evidence on lung cancer and environmental tobacco smoke. Br. Med. J. 1997, 315, 980-988. [CrossRef]

141. Gross, A.J. Presentation: The risk of lung cancer in nonsmokers in the united states and its reported association with environmental tobacco smoke. J. Clin. Epidemiol. 1995, 48, 587-598. [CrossRef]

142. Tweedie, R.L.; Scott, D.J.; Biggerstaff, B.J.; Mengersen, K.L. Bayesian meta-analysis, with application to studies of ETS and lung cancer. Lung Cancer 1996, 14 (Suppl. 1), S171-S194. [CrossRef]

143. National Research Council (US) Committee on Passive Smoking. Environmental Tobacco Smoke: Measuring Exposures and Assessing Health Effects; National Academies Press (US): Washington, DC, USA, 1986; ISBN-10: 0-309-03730-1.

144. Blot, W.J.; Fraumeni, J.J. Passive smoking and lung cancer. J. Natl. Cancer Inst. 1986, 77, 993-1000. [PubMed]

145. Wells, A.J. An estimate of adult mortality in the united states from passive smoking. Environ. Int. 1998, 14, 249-265. [CrossRef]

146. Lee, P.N. Environmental Tobacco Smoke and Mortality; Karger: New York, NY, USA; Basel, Switzerland, 1992; Volume 1, pp. 110-118(119).

147. U.S. Environmental Protection Agency; Office of Health and Environmental Assessment. Respiratory Health Effects of Passive Smoking: Lung Cancer and Other Disorders, 1st ed.; National Academies Press: Washington, DC, USA, 1993.

148. Pershagen, G. Epidemiology of Lung Cancer, 1st ed.; Marcel Dekker: New York, NY, USA, 1994.

149. Mengersen, K.L.; Tweedie, R.L.; Biggerstaff, B. The impact of method choice on meta-analysis. Aust. N. Z. J. Stat. 2010, 37, 19-44. [CrossRef]

150. Dockery, D. Environmental Tobacco Smoke and Lung Cancer: Environmental Smoke Screen; CRC/Lewis: New York, NY, USA, 1996; Volume 90, pp. 309-323.

151. Zhao, H.; Gu, J.; Xu, H.; Yang, B.; Han, Y.; Li, L.; Liu, S.; Yao, H. Meta-analysis of the relationship between passive smoking population in China and lung cancer. Zhongguo Fei Ai Za Zhi 2010, 13, 617-623. [CrossRef] [PubMed]

152. Wald, N.J.; Nanchahal, K.; Thompson, S.G.; Cuckle, H.S. Does breathing other people's tobacco smoke cause lung cancer? Br. Med. J. (Clin. Res. Ed.) 1986, 293, 1217-1222. [CrossRef]

153. Saracci, R.; Riboli, E. Passive smoking and lung cancer: Current evidence and ongoing studies at the international agency for research on cancer. Mutat. Res. 1989, 222, 117-127. [CrossRef]

154. Law, M.R.; Hackshaw, A.K. Environmental tobacco smoke. Br. Med. Bull. 1996, 52, 22-34. [CrossRef] [PubMed] 
155. Tweedie, R.L.; Mengersen, K.L. Lung cancer and passive smoking: Reconciling the biochemical and epidemiological approaches. Br. J. Cancer 1992, 66, 700-705. [CrossRef] [PubMed]

156. Li, M.; Liu, X.; Zhang, L. The relationship of indoor coal use and environmental tobacco smoke exposure with lung cancer in China: A meta-analysis. J. Cancer Res. Ther. 2018, 14, S7-S13. [CrossRef] [PubMed]

157. Yu, Y.W.; Wang, C.P.; Han, Y.F.; Niu, J.J.; Zhang, Y.Z.; Fang, Y. Meta-analysis on related risk factors regarding lung cancer in non-smoking Chinese women. Zhonghua Liu Xing Bing Xue Za Zhi 2016, 37, 268-272. [CrossRef] [PubMed]

158. Fu, X.; Feng, T.; Wu, M.; Zhang, L.; Jiang, C. Relationship between environmental tobacco smoke and lung cancer risk among nonsmokers in China: A meta-analysis. Chin. J. Prev. Med. 2015, 49, 644-648.

159. Levois, M.E.; Layard, M.W. Inconsistency between workplace and spousal studies of environmental tobacco smoke and lung cancer. Regul. Toxicol. Pharmacol. 1994, 25, 309-316. [CrossRef] [PubMed]

160. Bero, L.A.; Glantz, S.A.; Rennie, D. Publication bias and public health policy on environmental tobacco smoke. JAMA 1994, 272, 133-136. [CrossRef] [PubMed]

(C) 2018 by the authors. Licensee MDPI, Basel, Switzerland. This article is an open access article distributed under the terms and conditions of the Creative Commons Attribution (CC BY) license (http://creativecommons.org/licenses/by/4.0/). 